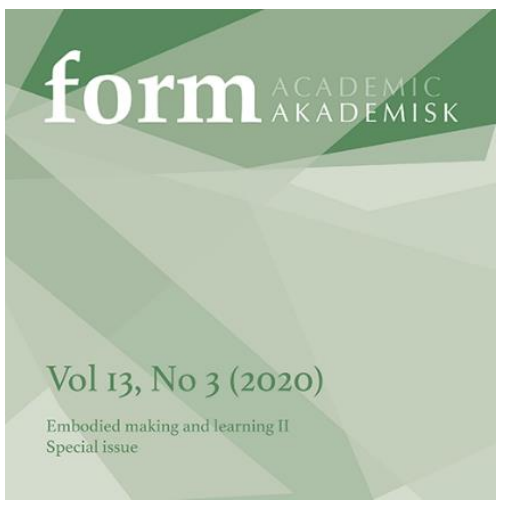

Kirstine Riis

Associate Professor, PhD

University of South-Eastern Norway

Faculty of Humanities, Sports and Educational Science

Department of Visual and Performing Arts Education kirstine.riis@usn.no

Associate Professor II, Doc

University of South-Eastern Norway

Faculty of Humanities, Sports and Educational Science

Department of Visual and Performing Arts Education and University of Gothenburg

Department of Conservation camilla.groth@usn.no

\title{
Navigating methodological perspectives in doctoral research through creative practice
}

\author{
Two examples of research in crafts
}

\begin{abstract}
Methodologies for conducting academic research in crafts through practice-led approaches are still emerging, and research methods are developing with each project. Through this article, we navigate the field from a doctoral candidate's perspective, presenting the research field and some central issues researchers are confronted with in regard to epistemology, methodology and methods. We exemplify the arguments made through our own doctoral projects to solidify the points. The article discusses the methodological perspectives of these research projects, how and why they developed and changed over time and how they were influenced by external circumstances. We especially emphasise the challenges and opportunities of practice-led research in crafts and highlight the type of contribution to be had and its relevance for the practice field and related education.
\end{abstract}

Keywords:

Doctoral study, research methodology, creative practices, craft research, experiential knowledge, embodied making. 


\section{INTRODUCTION}

What is research in the field of creative practice? How does one study one's own practice from an insider perspective while keeping a general relevance? What theories are relevant? Which methods can be used? How do you handle the relationship between practice and research? In this article, we discuss these common questions and the central issues novice researchers are confronted with when planning their research through craft practice. Linking theoretical, epistemological and methodological aspects in an integrated understanding is fundamental to make a research project consistent. Often these aspects are interwoven in a complex network that is challenging for novice researchers to manage, especially in a context and research tradition that is still emerging.

The intention of this article is to provide an overview and insight into the research field of creative practices with a special focus on craft research, outlining central concepts, contexts and research traditions, but also to point to interrelations amongst these. In order to do this in the limited space of an article, it is necessary to make some generalisations. We are aware that the particularities of each context and methodological approach will suffer in this treatment but find it necessary in order to present an elementary overview of the research landscape. The understanding presented here is based on our own experiences as craft researchers, and the review reflects our situated perspective, not a general, systematic or complete description of the field.

For the purpose of this article, we primarily refer to craft research in the Nordic context since our research processes are situated in Norway and Finland. However, as research fields do not develop in a vacuum, we also relate to developments in the international craft research field. Craft is studied in more than one context; therefore, several contextual cultures of craft research have developed in primary school education and vocational craft research and in the professional arts and crafts and related higher education. In the overview, we will describe some of these environments.

The borderlines amongst art, craft and design might be diffuse in some cases, but, ultimately, these contexts have much in common when it comes to research practices and doctorateness. DuninWoyseth and Michl (2001) referred to the making disciplines rather than making any clear distinctions amongst these. The making disciplines denominate creative practices on a general level and include, for example, 'art production, object design, industrial design, architecture, landscape architecture, urban design and spatial planning' (Dunin-Woyseth \& Michl, 2001, p. 1) but are still focused on material interactions, i.e. not including the performing arts such as dance, music or theatre etc.

We use the general term creative practice as the greater context in which our examples from the field of crafts are situated, and this context moves amongst the arts, crafts and design fields. Extracts from the two author's doctoral studies on experiential knowledge in crafts are used as examples to discuss the above questions and ways of navigating challenges and opportunities in research through creative practice.

\section{Research on and through creative practice from a Nordic perspective}

Over the past 40 to 50 years, there has been an ongoing discussion in the field of creative practices about the relation between practice and research in academia. Already from the middle of the 1970s, the national authorities demanded a more academic and research-oriented profile for schools of architecture in the Nordic countries (Dunin-Woyseth \& Michl, 2001, p. 4). Frayling's (1994) definition of research into, on and through art and design, which was a response to the demands on research quality set by the British Research Assessment Exercise (RAE), has set some basic parameters for what is defined as research through art and design, or a practice-led research approach in which one's own practice is used as a research method (cf. Rust et al., 2007).

Throughout the years, different traditions, contexts, concepts and names have emerged to describe research through creative practices, such as art-based research, artistic research, practicebased research, practice-led research, research through design, research by design etc. This variety of concepts is both a consequence of the field of creative practices being an evolving research field, but also illustrates creative practices as multifaceted and indefinite as well as subjected to external and contextual constraints. This, again, makes it more complex to navigate in this research landscape. The boundaries of doctorateness in the field were set by general regulations in the Bologna 
Process that aimed to be similar for all European doctors (Bologna Working Group on Qualifications Frameworks, 2005). In Solberg's dissertation (2017), she investigated how the making of art and design in nine doctoral works responded to the criteria of doctorateness in these European formal frameworks. The Bologna Process stipulated additional requirements for the PhD, noting that it should be a comparable achievement across subjects and disciplines, thus not accepting artefacts as research contributions.

The Doctor of Art degree, which allows inclusions of artistic outputs is a solution to the restrictions stipulated by the Bologna Process. However, the research landscape is still in a formative process in which national traditions and ways of interpreting the restrictions are developed independently (Solberg, 2017). The pace of introducing doctoral study through one's own practice varies greatly when compared on an international level; the degree has been available to candidates since the early 1990s in Britain, Australia and Finland, with the first Finnish practice-led doctorate student graduating in 1997 (Eskola, 1997), in Norway in 2000 (Refsum, 2000; see also Capjon, 2004; Stenslie, 2010) and in Denmark 2015 (Hasling, 2015). The degree was quite recently accepted in Sweden, with the first Swedish applied arts doctorate defended in 2016 (Medbo, 2016).

However, these doctorates have paved the way for new generations of practitionerresearchers who look for ways to conduct craft research through their own practice. Studies focusing on the actions in the practice and on the understandings that emerge in the close and attentive study of one's own actions and movements are under development at the University of Gothenburg, Department of Conservation (Eriksson, 2019; Eriksson et al., 2019; Jarefjäll, 2016; Källbom et al., 2019; Seiler, 2020). There, the concept of Craft Sciences (Almevik, 2019; see also Westerlund et al., in press) is developed as a discipline formed by a collection of craft practices from various fields that connect through their orientation towards creative and material processes and craftsmanship.

Studies on craft by craft practitioners in academia have long traditions in the Nordic countries due to craft education in preliminary schools and the related craft teacher education and research activities. In the period from 1995 to 2010, students from the field of design pedagogy in Norway were included in the doctoral program at The Oslo School of Architecture and Design (AHO), which contributed to developing a broader platform for this kind of research characterised by 'doctorateness' and 'critical mass' (Dunin-Woyseth \& Nilsson, 2012; Nielsen, 2018) and community knowledge (Fauske, 2016). Several Norwegian PhDs have been awarded in design pedagogy from both AHO e.g. (Brænne, 2009; Digranes, 2009; Lutnæs, 2011), and other Norwegian universities (Randers-Pehrson, 2016; Rimstad, 2014; Skredli, 2016), and Finland (cf. Åbo Akademi, Carlsen, 2015; Dagsland, 2013)

In Finland, the concept of craft sciences was already formed in the early 1990ies in the field of craft teacher education. Pirita Seitamaa-Hakkarainen's (2001) research in the educational context, for example, focused on expertise, collaborative making and the introduction of new technology and materials in the school subject. Affiliations in Turku and Rauma (Hartvik, 2014; Lindfors, 2002; Pöllänen, 2015; see also Kokko, 2018) have studied the well-being and social aspects of crafts. Inter-Nordic joint efforts and collaborative research is common via networks such as Nordfo and Nordforsk (cf. Kokko et al., 2020). Swedish craft teacher education has a long tradition, and several doctoral theses have been produced on the pedagogical aspects of the Sloyd (craft) subject, mainly through classroom studies conducted by teachers or teacher trainees (see, for example, Hasselskog, 2010; Johansson, 2002). However, until recently, few doctoral studies in the field of teacher education in arts and crafts have conducted research through their own practice, even though many craft teacher educators are naturally craft practitioners themselves, and thus have embodied knowledge about the craft processes they study through their student participants (Johansson, 2018, p. 114).

\section{Research through creative practices as an approach and research paradigm}

The epistemological artefact is an elemental aspect of research in creative practices, where much of the data is material laden and aesthetic aspects are paramount, but all practice-led studies do not necessarily present the artefact as a result of the research. In this section, we will provide different understandings and contributions to research through practice. 
While research through practice is not a method per se, it could instead be called a 'methodological approach'. This is part of a paradigm shared with other practice fields in which it is central to have a close connection to the actual actions and events under study and in which the practitioner-researcher is a central informant. Biggs and Karlsson (2011) noted that the 'arts research paradigm' develops in the interaction between artistic practice and theory as a hybrid where the research is not either practice or research but something new $(2011$, p. 409). They described the arts research paradigm as 'a third professional category that is as yet undefined' (p. 423) and encouraged expertise in the field to develop and explore methodologies specific and relevant for the current expertise (p. 410).

As crucial for doctorateness in this context, Dunin-Woyseth and Nilsson highlighted the need for awareness of the knowledge landscape in which the professional researcher has to navigate and the ability to communicate and engage in dialogue with peers, professionals and other knowledge producers in the field $(2012$, p. 9). Research through creative practice allows for experiential and embodied knowing from inside the practice to be documented, analysed and distributed in a way that an objective or distant approach will not facilitate.

Although still forming its research traditions, craft research is gaining strength through the many recent research contributions in the field (Aktaş \& Mäkelä, 2019; Glitsch, 2020; Jarefjäll, 2016; Källbom, Nilsen \& Öström, 2019; Mäkelä, 2016). Many of these have acknowledged the body and forms of bodybased knowing that have a strong subjective and experiential nature (cf. Niedderer, 2013; Nimkulrat, 2012). Biggs and Karlsson (2011, p. 422) claimed that there are no 'off-the-shelf methods' to teach novice researchers because there are no 'off-the-shelf-problems'. They thus encouraged developing a research framework in relation to specific problems, contexts and recipients.

\section{Some general methodological directions in research conducted through creative practice}

When it comes to the choice of methodology for research that is conducted through creative practice, some dominating methodological approaches emerge. The following section presents a brief overview based on our situated point of view and is not based on a systematic analysis but rather on the methodologies we have encountered as researchers and teachers in the field. Research in the creative practices often follows a phenomenological line of enquiry, through hermeneutical reflection between theory and practice, utilising self-study and autoethnographic data collection methods.

Another line of enquiry is the pragmatic orientation, drawing on Dewey (1934), Schön, (1983) Sennett (2009). More recently, sociological directions such as practice theory (Gherardi, 2000; Nicolini, 2009) have interested researchers. In such practice research, the researcher is seeking to place the practice in a wider context including social patterns and interactions amongst the practitioner and other practitioners, material mediation and material culture (Gherardi, 2000) as well as describing practitioners as members of communities of practice (Lave \& Wenger, 1991). The researchers in this context may sometimes be practitioners themselves, but this is not always the case (see also the four different basic modes of design research by Niedderer, 2013, p. 11).

In some creative practices, especially in the branch of artistic research, practice is acknowledged as research in its own right (Candy \& Edmonds, 2018). However, when artistic research is brought into the academic context, the methodology and the purpose of the research might need to conform to the existing academic traditions and constraints (Solberg, 2017).

When creative practice leads the research process, we often refer to the concepts as practicebased and practice-led research. There are several understandings of what practice-led research involves or what its focus is (for an overview see Candy \& Edmonds, 2018; Mäkelä, 2007; Mäkelä, et al., 2011; Mäkelä \& Nimkulrat, 2018). Candy and Edmonds (2018, p. 63) claimed that the use of terminology concerning practice-based research 'has not yet been characterized in a way that is agreed upon across the variety of disciplines of where it is used in'. They suggested distinguishing between practice-based and practice-led research; in practice-based research, the creative works arising from the research process make the basis of the contribution to knowledge and are included in the submission, and in practice-led research, the research primarily leads to new understandings about practice, but does not depend upon the creation of an artefact (p. 65). Even if the artefacts are not necessarily made for an exhibition, they play a central part in the data and methodology of the research design in most practice- 
based and practice-led research. The artefacts are also central to the output of the research as they speak a different language than the textual article; therefore, methods for disseminating research through multimodal means have become important. Another way for creative practitioners to reflect on their practice in writing is to use creative writing practices such as narrative life writing for data and as a base for reflections on their practice and artistic processes (Livholts, 2015; Medbo, 2016).

The term Practitioner-research is sometimes used interchangeably with action research, designbased research and self-study (Campbell, 2013; Sawyer, 2006, see also Pinnegar \& Hamilton, 2009). The assumption is that the informed practitioner is the best person to analyse the practice under investigation, as an outsider would not have the same ability to detect what is important to that practice (McGuirk \& Methi, 2015). The field of craft is special in this realm because it consists of expert knowledge that is difficult and time-consuming to acquire and thus benefits from the insider's perspective in the research process. Practitioner-researchers in crafts have also contributed to knowledge in other fields, such as anthropology and archaeology, through creating craft experiments to test hypotheses (Høgseth, 2007). In turn, they have benefitted by adopting methods from the science fields to advance craft knowledge in historical studies (Nyström, 2020) or from the vocational fields (Källbom et al., 2019) and by employing methods developed in human geography to visualise actions and knowledge in craft practice (Eriksson et al., 2019).

As noted above, methodological approaches in creative contexts lean on different philosophical academic traditions, such as the social sciences and humanities and borrow methods from these while adapting them to better suit their own purposes, demands and research enquiries. In Table 1, we present an intermediate and very general summary of the above presentation. This overview of methodological approaches that we have seen in research conducted through creative practice is not exhaustive and is rather meant as a starting point for navigating in the methodological landscape. The table shows which academic traditions, epistemologies and theories these approaches may be connected with and the methods often used. 
TABLE 1. Typical methodological approaches used in research through creative practice.

\begin{tabular}{|c|c|c|}
\hline Methodological approach & Method & Epistemology and theory \\
\hline $\begin{array}{l}\text { Practice-based and practice-led research } \\
\text { approaches }\end{array}$ & $\begin{array}{l}\text { Autoethnographic documentation of } \\
\text { practice and related reflections }\end{array}$ & $\begin{array}{l}\text { Philosophy, social sciences, } \\
\text { Pragmatism, artistic research }\end{array}$ \\
\hline Visual studies & Visual ethnography & $\begin{array}{l}\text { Artistic research, anthropology, } \\
\text { art history }\end{array}$ \\
\hline Phenomenological approach & $\begin{array}{l}\text { Phenomenological descriptions and } \\
\text { analysis, phenomenography }\end{array}$ & Philosophy, phenomenology \\
\hline Hermeneutic approach & Interpretive (textual) analysis & Philosophy, hermeneutics \\
\hline Action research & $\begin{array}{l}\text { Field study/participatory observation, } \\
\text { classroom study }\end{array}$ & Social sciences \\
\hline $\begin{array}{l}\text { Design research, } \\
\text { Research through design }\end{array}$ & $\begin{array}{l}\text { User studies, co-creation, Interventions, } \\
\text { design process, } \\
\text { iterative prototyping }\end{array}$ & $\begin{array}{l}\text { Constructivism, design thinking, } \\
\text { design cognition, }\end{array}$ \\
\hline Grounded theory & $\begin{array}{l}\text { Literature studies, interviews, } \\
\text { observations }\end{array}$ & Social sciences/Psychology \\
\hline A/R/Tography & Self-study/Classroom study & Art teacher education \\
\hline $\begin{array}{l}\text { Historical research through craft } \\
\text { experiments }\end{array}$ & $\begin{array}{l}\text { Deconstruction/Reconstruction, } \\
\text { experimental archaeology }\end{array}$ & Conservation/Archaeology \\
\hline Narrative discourse & $\begin{array}{l}\text { Reflective narratives and life story } \\
\text { writing as data for research, discourse } \\
\text { analysis }\end{array}$ & $\begin{array}{l}\text { Artistic research, vocational } \\
\text { practice research, sociology, } \\
\text { discourse theory }\end{array}$ \\
\hline Sensory and action-based studies & $\begin{array}{l}\text { Time-space geography, } \\
\text { visual narratives, } \\
\text { cartography, repertory grid, } \\
\text { sensory ethnography }\end{array}$ & $\begin{array}{l}\text { Human geography, cultural } \\
\text { geography, sensory geography, } \\
\text { anthropology, social sciences, } \\
\text { organizational studies }\end{array}$ \\
\hline $\begin{array}{l}\text { Educational research in the arts, craft } \\
\text { and/or technology subjects }\end{array}$ & Co-creation, observation & $\begin{array}{l}\text { Learning sciences, design } \\
\text { cognition, pragmatism }\end{array}$ \\
\hline Qualitative case study methodology & $\begin{array}{l}\text { Various: Observation, interviews, field } \\
\text { study, one's own production }\end{array}$ & Social science/Psychology \\
\hline
\end{tabular}

As outlined above, there is a relationship between the epistemological traditions that maintain methodologies and methods that are relevant in that context. If these are combined without paying attention to their compatibility, the research process might be jeopardised because of the discrepancies that follow from perspectives being unaligned. The novice researcher would be encouraged to navigate these epistemological bases in order to design the general methodology of their research.

In the next section, we attempt to navigate amongst some of these methodological aspects in craft research. For this purpose, we have developed a model (Figure 1) to be able to visualise how epistemology, methodology and methods are interrelated issues in research through craft practice. Theory is considered integrated in all layers in the model. 


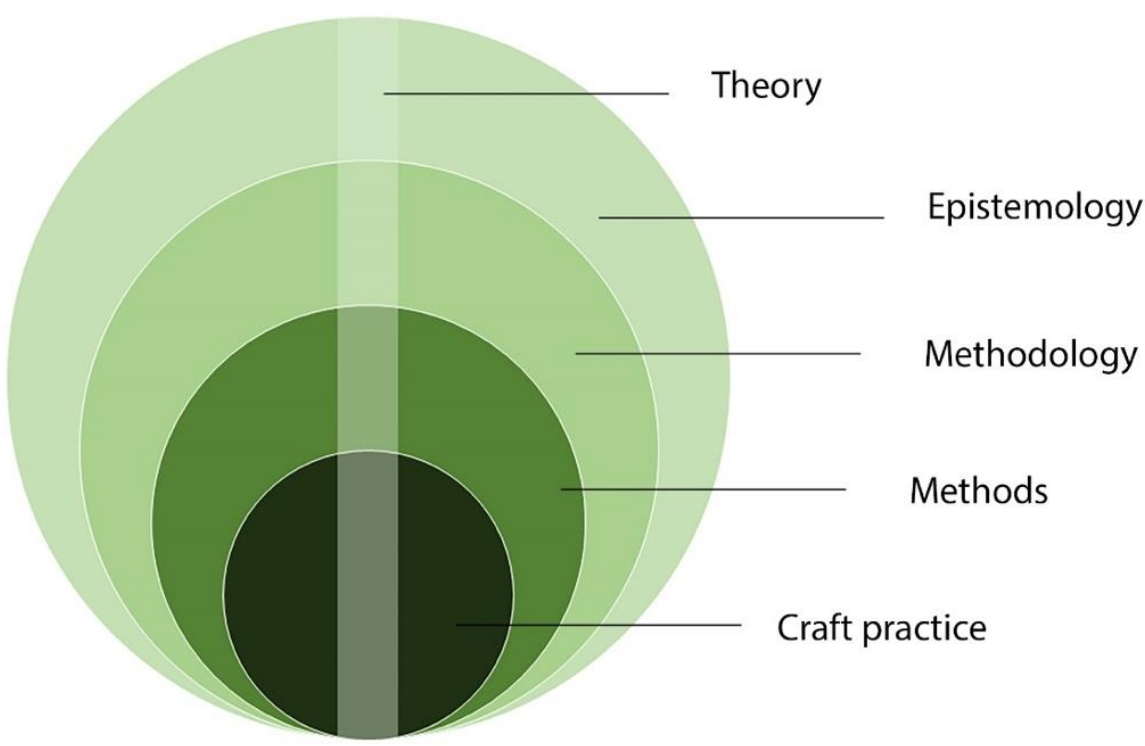

FIGURE 1. Interrelated issues in craft research: theory, epistemology, methodology, methods and practice.

We will use this model when we present the two doctoral studies in more detail as we discuss different issues that a practitioner-researcher might encounter in the research processes, regardless of craft context. Our methodological choices are explained according to the layers in the model. Finally, we sum up general advice for researchers in their early career. In this way, we hope to prepare novice researchers in their research design processes and navigation in this research field.

\section{EXAMPLE CASES: TWO DOCTORAL STUDIES IN CRAFTS}

The two doctoral study examples in this article, Groth (2017) and Riis (2016), both utilised a practiceled approach in the study of experiential and embodied aspects of craft practice from a practitionerresearcher perspective. The focus of the cases presented in this article is on the processes of the practice, not only where the practice might result in a product but also where the craft practice is primarily conducted to inform research and consequently also feed back into the practice. The methods used followed a qualitative research methodology with explorative autoethnographic elements. As the article format does not allow us to explain the projects in depth, we focus here on the methodological aspects. However, both dissertations are available with open access at Groth (2017) and Riis (2016).

\section{Groth 2017}

Groth's dissertation title is: Making Sense through Hands: Design and Craft Practice Analysed as Embodied Cognition. Groth, as a ceramist, started with studying body-based knowing and tactile experiences in the field of ceramic practice. Her general research question was: How do design and craft practitioners make sense through their hands? This was explored through three case studies: Case 1: workshops and interviews with deaf and blind people on their experiences of making ceramics; Case 2: throwing clay blindfolded herself (Figure 2); and Case 3: the study of how design students utilise their experiential and embodied knowledge in their processes. 


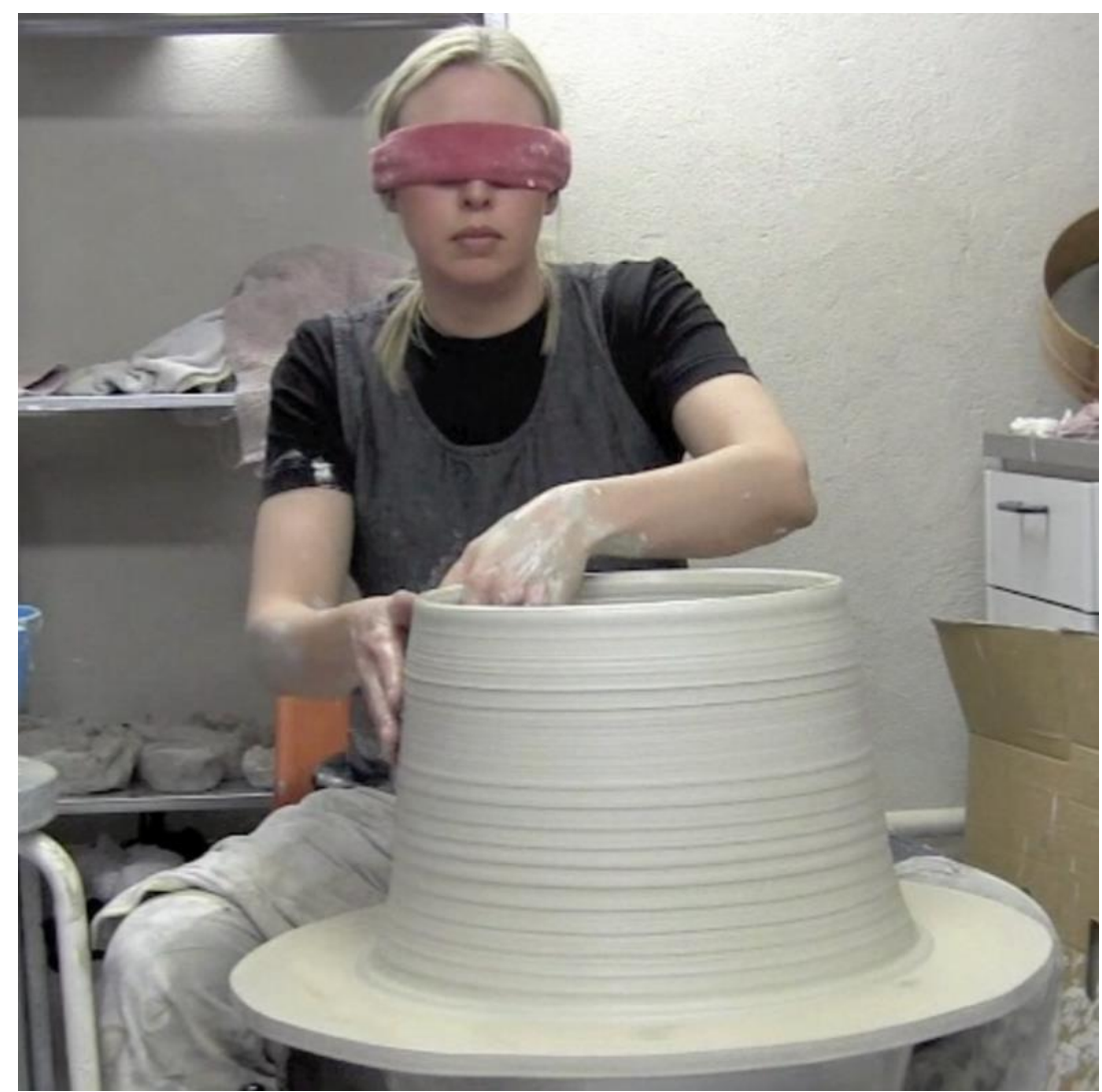

FIGURE 2. Groth's autoethnographic self-study. Screenshot from a video recording of the research event.

Groth's research was influenced by the two different institutions in which her research work was conducted as the research project was a mutual undertaking she was involved in during her doctoral studies. This led her to go from a theoretical framing in design cognition towards the theoretical foundations of embodied cognition, while exploring methods and concepts in relation to both backgrounds.

A research group at Aalto University formed the home base for the study. As the research culture of the group nurtures artistic and practice-led methods in the field of design, this environment influenced the methodology. However, the study was conducted as part of a larger research consortium, and thus, it was also informed by traditions of academic craft science study at the University of Helsinki. Groth's study contributed to the Handling Mind (n.d.) project within the broader context of studying craft and design practices from an educational, cognitive and well-being perspective.

The interrelated layers of epistemology, methodology, methods and theory in Groth's research are illustrated in the model in Figure 3. 


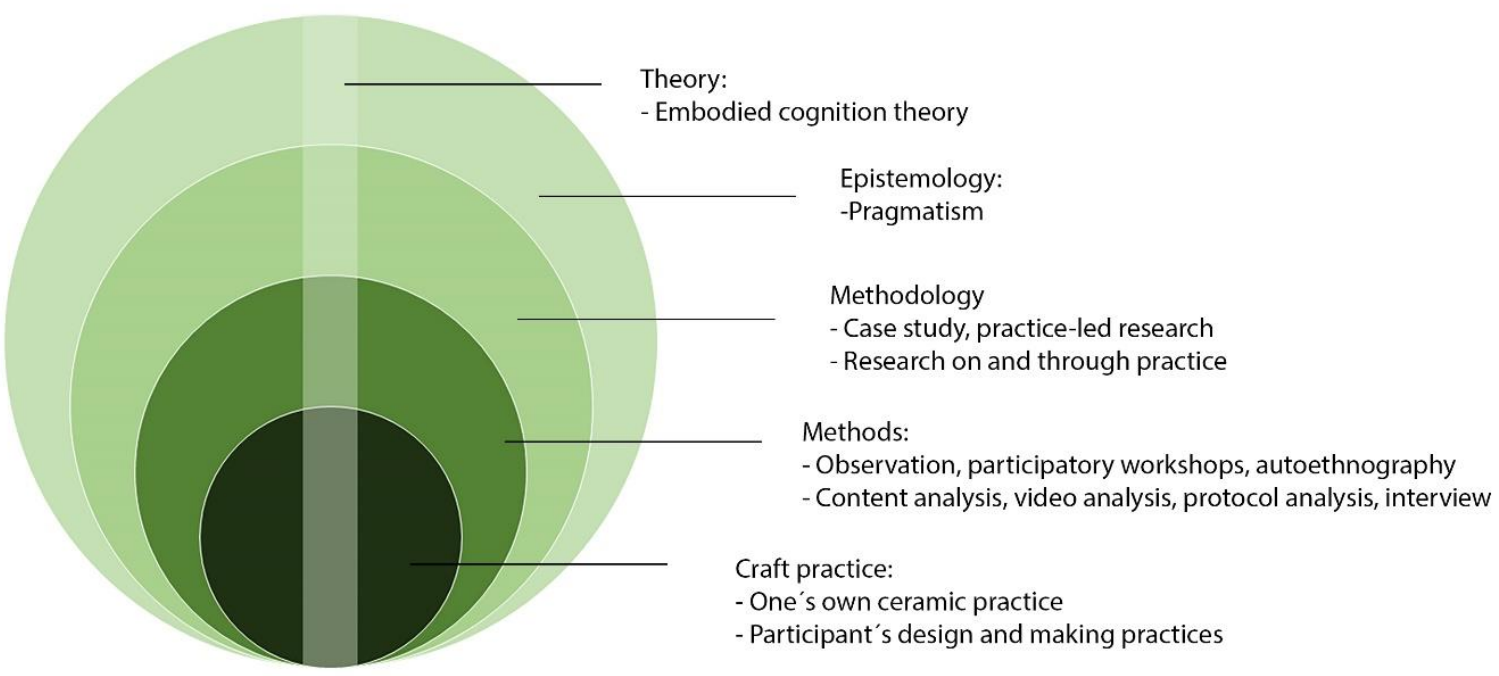

FIGURE 3. Model illustrating Groth's methodology.

\section{Riis, 2016}

Riis's dissertation title is: The DNA of Design Knowledge. Exploring Design Knowledge through the Design Process My DNA. Riis investigated design knowledge through her own craft process while she was forming textile materials into three dresses inspired by the DNA molecule (Figure 4).

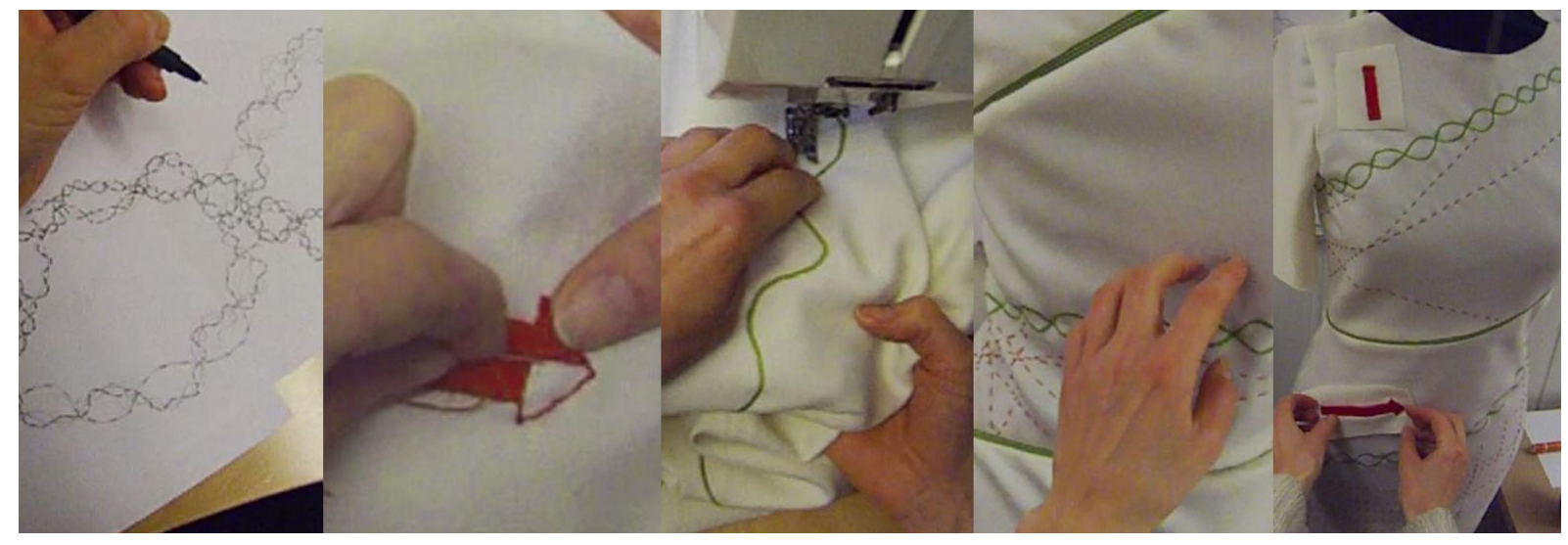

FIGURE 4. Photos from Riis's design process .

The research was conducted from the perspective of her own craft knowledge, which integrated epistemological, methodological and didactical aspects. Riis's research was divided into three parts, called design-dialogues (DD1, DD2, DD3), where the following research questions were explored: What characterises design knowledge? How is craft and design knowledge developed and given form? How is design knowledge and knowledge about design knowledge developed, expressed and communicated? Riis's research was influenced by three different academic fields. The first is a traditional university context namely The Norwegian University of Science and Technology (NTNU) and the doctoral program in Humanities and the Arts. The second is the Norwegian National Research School in Teacher Education 
(NAFOL), and the third is the Norwegian arts and craft education in Notodden now as part of University of South-Eastern Norway that has a 45-year tradition of master studies in design, arts and crafts (Fauske, 2014; Melbye, 2003). During Riis's doctoral study, the research group Embodied Making and Learning (EMAL) was established, and Riis became a member of the research group. A key influence became Riis's main supervisor Bengt Molander and his theory of knowledge articulated in The Practice of Knowing and Knowing in Practice (Molander, 2015). The interrelated layers of epistemology, methodology, methods and theory in Riis's research are illustrated in the Figure 5.

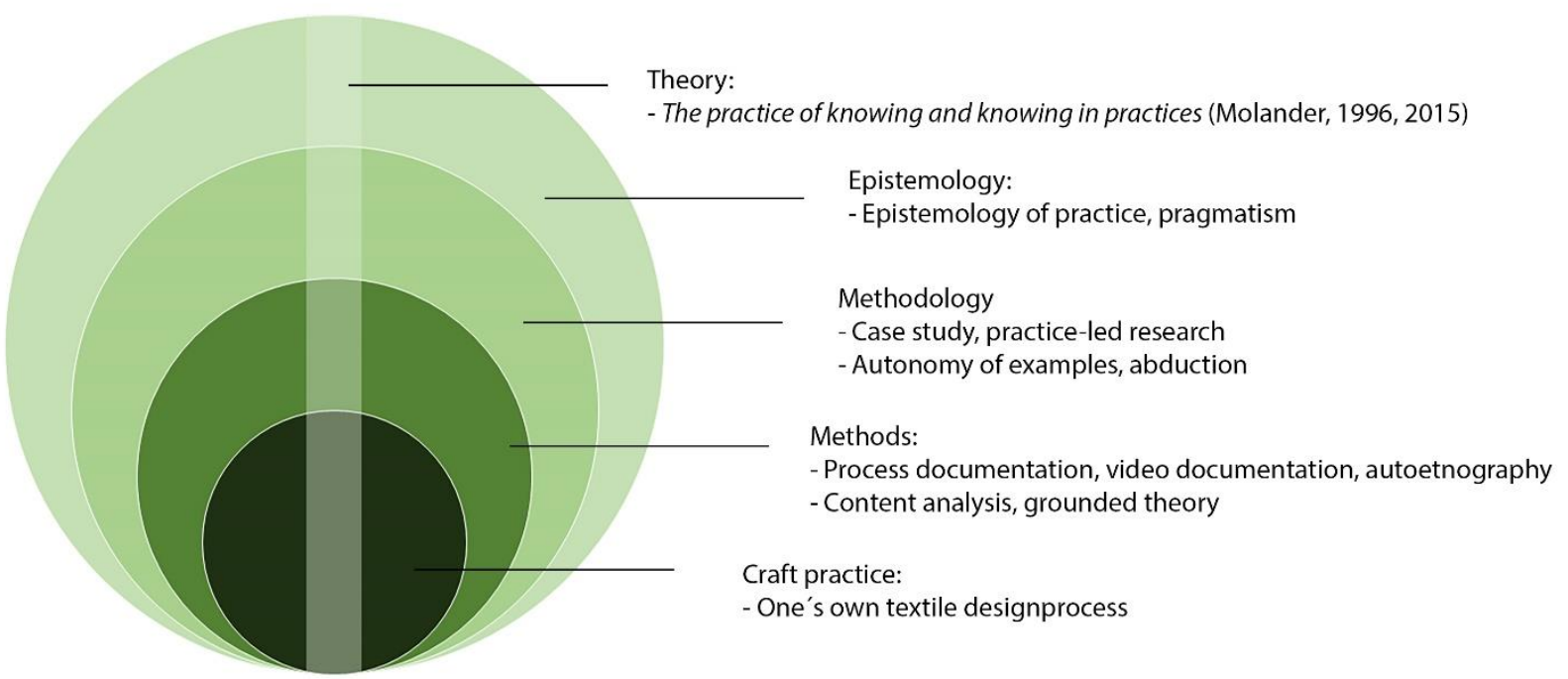

FIGURE 5. Model illustrating Riis's Methodology

\section{NAVIGATING THEORETICAL, EPISTEMOLOGICAL AND METHODOLOGICAL ASPECTS IN CRAFT RESEARCH}

Discussions on research in creative practices often deal with the relations between practice and theory. In this article, we do not consider theory as a separate layer in the matrix shown above, but rather as an aspect of all layers and integrated in the epistemological stance in general.

\section{Theory - experiential knowledge through practice}

Academic research uses theoretical frameworks, concepts etc. to analyse empirical data and to discuss research findings. Research in an academic context also generates new theory as a contribution to knowledge in the research field. This means that the theory used is a perceptual lens through which the phenomena under study is understood as well as treated, and it also largely dictates the possible outcomes of the study. Therefore, even if the theories behind the methods for data collection might be different from the theories behind the methods for analysis, they cannot be grounded in fundamentally different epistemologies. For example, trying to study one's own craft practice through an objective lens will be very challenging.

Thus, to investigate craft practice as experiential knowledge requires a certain epistemological positioning from the outset. With references to embodied cognition theory and practice epistemology, both research projects emphasised the complexity and nonverbal, sensuous aspects of knowledge. According to Niedderer (2013) and Molander (2015), propositional and non-propositional knowledge are presumed as two sides of a coin and as interrelated tensions, meaning that they are inseparable. In craft practice, and any other practice or physical experience, we include all psychophysical aspects and 
do not separate them in our experiences. Studies in the field of experiential knowledge in the creative field have thus utilised concepts such as tacit knowledge (Polanyi, 1966) and aesthetic experience (Dewey, 1934).

Developing the pragmatic stance in the study of crafts, Sennett (2009) has contributed with insightful discussions on the craftsman's way of thinking and knowing through hands and in the use of handheld tools. Schön (1983) encouraged practitioners to reflect both in and on their actions, in order to better understand what those actions are for and how to possibly enhance and make these better. In his theory of knowledge, outlined in The Practice of Knowing and Knowing in Practice, the Swedish philosopher Molander (2015) described knowing as existing in the moment of action and being closely tied to the practicing act itself (see also Noë, 2004). Molander described knowledge as a living phenomenon which is always developing and, as such, is understood as learning. Tensions are fundamental to this perspective of knowledge, and Molander emphasised overarching tensions between sensuous experiences and conscious and conceptual understanding. Molander (2015, p. 263) stated, 'The knowledge in action that emerges is largely to do with attentiveness, attentiveness in action'.

Experiential knowledge relates both to embodied cognition (Johnson, 2007; Lakoff \& Johnson, $1980,1999)$ and the tradition of phenomenology, that speaks of the body as integral in all sense-making; thus actions are especially key in knowledge formation. Within each of these two traditions, the fields are even further separated amongst philosophy, psychology, neuroscience and biology. While these traditions have developed the idea of the embodied mind within their very separate disciplines, there is also a tendency to refer across the disciplinary borders and to build on each other's understandings (see, for example, Johnsson, 2007; Noë, 2004, 2009). The above theories came to form the basis for the epistemological stance of the two example projects depicted here, but these were not self-evident at the beginning of the journey as we will discuss in the following section.

\section{Epistemology - researching experiential knowledge through practice}

Theoretical and methodological references were first introduced to us through our separate institutional contexts and the research traditions prevailing in those. For example, as for most craft researchers, it was clear that we would choose a qualitative research paradigm in line with Denzin and Lincoln's (2011, p. 3) view that 'qualitative research is a situated activity that locates the observer in the world' and that involves an 'interpretive and naturalistic approach to the world'.

In Groth's process of navigating the different theoretical fields proposed by the two institutional traditions that she was situated in, she first embarked on artistic research (cf. Borgdorff, 2007, 2012) and then familiarised herself with design studies and design cognition theory (cf. Cross, 2001). Having selected a fundamentally practice-related and material-based topic, the material interaction was not covered satisfactorily in the theory developed around design processes and design thinking. Here, pragmatism and embodied cognition theory gave the needed support for analysing reflections in and on bodily actions with materials. However, the final methodology developed in tandem between these environments and traditions.

Similarly, Riis also needed to navigate the theoretical landscape in the beginning of her project. Riis initially investigated design knowledge using Luhmann's systems theory (Luhmann, 2007), briefly explained as a metatheory based on the understanding of distinctions (inside or outside the system) (Riis, 2013). As she considered knowledge to be a living phenomenon instead of understanding it as merely theoretical, conceptual and describable with words, which is then testable and measurable, she recognised that it would not be possible to fully describe or capture the phenomenon she was studying. Therefore, she decided to instead draw and depict different sides of the phenomenon in different ways and modalities.

When Riis realised that her meta-reflection actually hindered the investigation of embodied aspects of knowledge, she turned to practice epistemology and the understanding of knowledge as developing in tensions amongst the sensuous, concrete and conceptual abstract aspects of knowledge. 


\section{Methodology - making and reflecting}

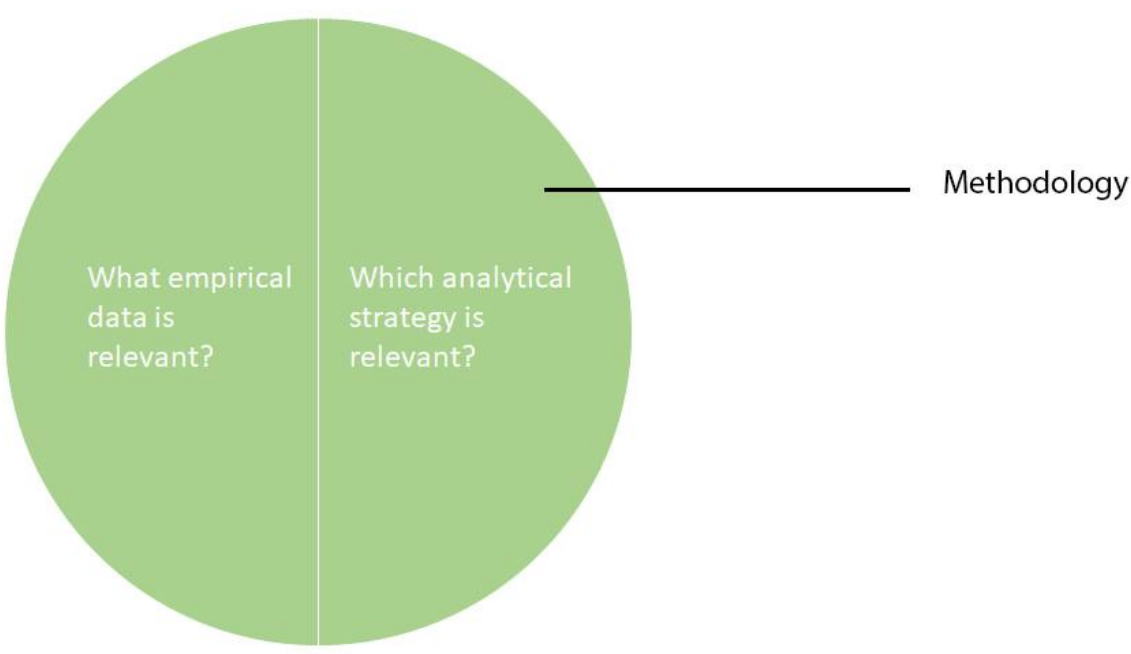

FIGURE 6. Model illustrating two aspects of methodology.

We consider methodology as a term for an overall research strategy. For example, in the introduction, we referred to practice-led research as a methodological approach. According to the model illustrated in Figure 6, methodological issues are seen both as a strategy for finding relevant empirical data to answer the research question and as an analytic strategy for reflecting on these. Both research projects utilised an explorative process in which the research design integrated possibilities to adjust methodological issues for the next case, based on experiences from the former case. Both Groth and Riis utilised a multiple case study design (Yin, 2009), but in slightly different ways. In Groth's research, the three study cases were organised in relation to the three perspectives on the same research question; thus, they were not comparative, but they were combined efforts in shedding light on the subject matter from different positions: the first case study was composed of several workshops and interviews with deaf and blind people on their experiences of making ceramics, focusing on their use of their haptic system. In the second case study, Groth wanted to apply what she had learnt from the first case. Obviously, the deaf and blind makers had an advantage over her in their refined tactile skills, but could she too enhance her own tactile skills by making them more sensitive? To find out, Groth created an event where she was throwing clay blindfolded in her studio for five consecutive days to test augmentation of her tactual sense. The main issue for the task was the challenge and control of the throwing process and the awareness of, or ability to, judge the shape and form of the piece solely with the hands. In the third case, Groth went on to study how design students utilised their experiential and embodied knowledge in their projects. To do this, she conducted an ethnographic study of design students with data gathered from the Design Exploration and Experimentation course conducted at the Aalto University, Design Department.

In Riis's research, DD1 was characterized as a case study investigating the first part of a textile design process. But in DD2 and DD3, the methodology was characterised by an explorative interaction between the design process and research process more than the study of the design process as a phenomenon. In the beginning of the project, the research and design process was distinguished (Figure 7, left), but throughout the process, the interplay between them became stronger, and tensions amongst practical, concrete and sensuous as well as theoretical, abstract and conceptual aspects of knowledge turned out to be preconditions for knowledge generation (Figure 7, right). 

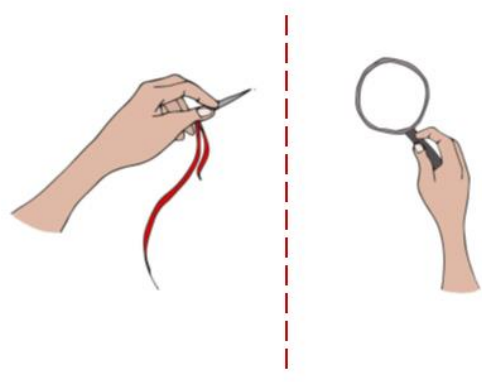

DD1: Practice-research distinction

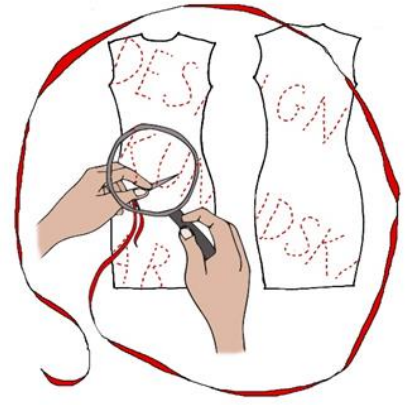

DD2, DD3: Practice-research integration

FIGURE 7. Illustrations of the different relations between practice and research in Riis's project.

In the end, Riis was doing more practice-based/artistic research than Groth, despite their different research institutions and expectations. Thus, at Riis's doctoral defence, artefacts such as dresses and posters were exhibited, though it was only the written thesis that was evaluated, as the artefacts were not allowed to be part of the research contribution at the time. Groth's doctoral research, on the other hand, in the end, did not include artefacts as research contribution, although this would have been allowed and encouraged at her University.

Both researchers found it important to keep the practice alive (Ingold, 2011; Molander, 2015) while conducting theoretical studies, in order to sustain the practical relevance and authenticity of the study. Groth created a purpose-made research event, that in a way did not have the natural setting seen in normal studio practices as she was blindfolded, but this allowed her to augment the experience and thus also highlight the aspects she was interested in. By collecting think aloud accounts, for example, she was able to reflect on her practice in action and articulate challenges, aspects of problem-solving and the related experiences and knowledge.

Riis found that it was essential to sustain herself as a making individual to be able to maintain the dynamic in the knowledge developing process - both in design and research. While having a making identity and, thus, being in dialogue with the concrete materials, confidence grew to explore new research methods and communicative possibilities. She found relevant theoretical threads in Molander's theory of knowledge, and to establish a concrete basis for the research and to be able to identify craft knowledge as a complex, multidimensional and dynamic form, Riis utilized textile metaphors and sewed on and through the empirical data with these threads. Thus, concrete materials and empirical data were sewn together, first in a metaphorical way, but later in a specific and concrete representation, as Riis depicted the research results in a dress (Figure 8). 

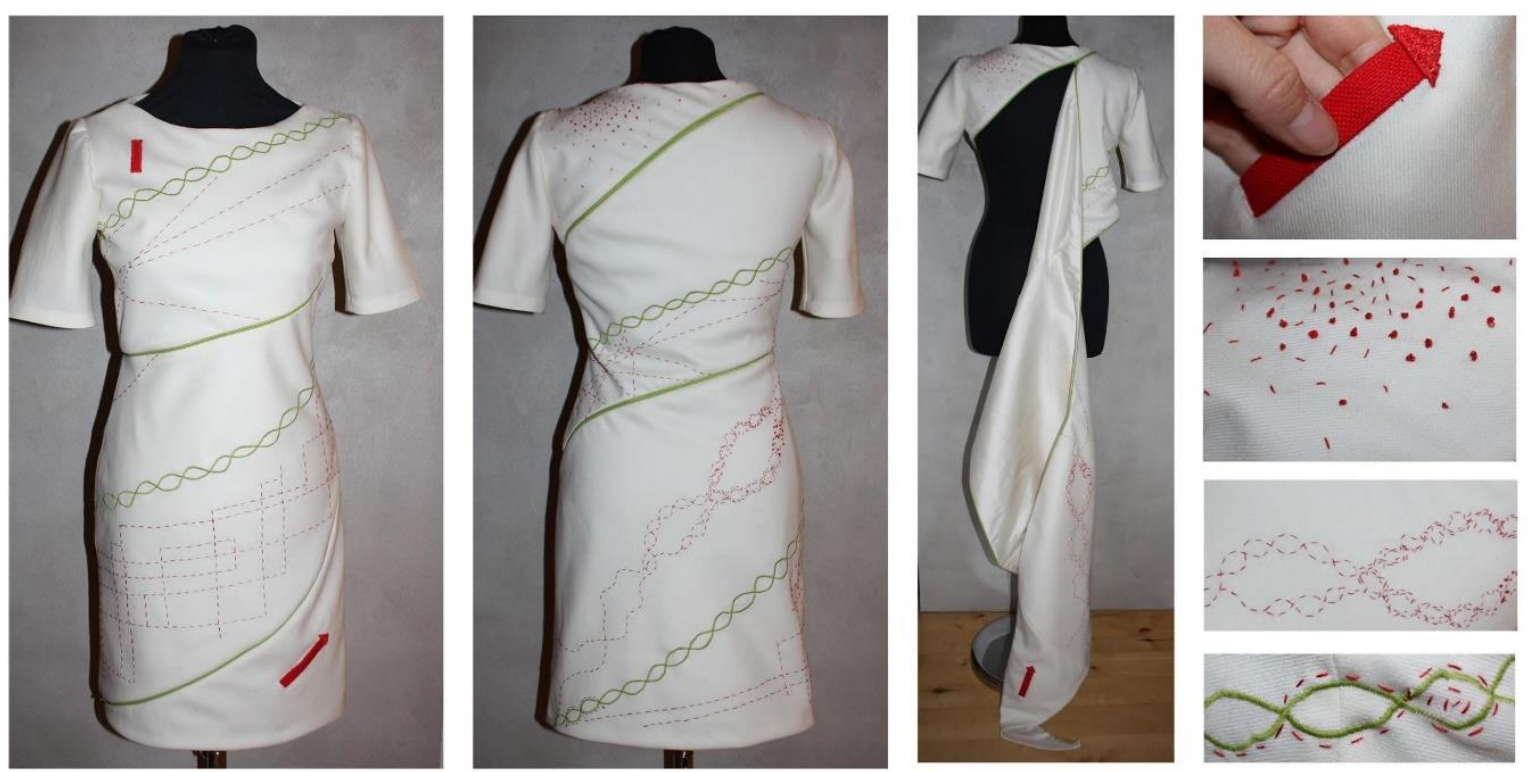

FIGURE 8. The dress depicting the research results in a multidimensional form and embroidered illustrations.

What analytical strategy is relevant is grounded in the logic that determines the generation of knowledge from the empirical data. Research analysis principles are often explained as either induction or inductive reasoning, letting theory grow from the analysis of empirical data, i.e. grounded theory/constructivist grounded theory (Charmaz, 2014) vs. the deductive approach, where theories are used to analyse and understand empirical data. A third concept, abduction means utilising existing knowledge in the identification of structures and meaning from the inductive investigation of empirical data. Abduction is often used in craft research, and Niedderer (2013) argued that abduction, as a mode of productive reasoning, is an appropriate framework because it is a creative and conjectural process (p. 21).

In Groth's three case studies, content analysis was used, supported by thematic and hybrid forms of inductive and deductive analysis as Groth became more informed about the theoretical frames of embodied cognition theory. Riis's analytic strategy was characterized by abduction. She began transcription of video analysis and open coding with references to constructivist grounded theory and inductive reasoning (Charmaz, 2017), but found that the dynamic between detailed examples and theoretical concepts/threads was the most constructive knowledge-generation.

Both Groth and Riis adopted the researcher's insider perspective and sought with their methodological strategies to facilitate interactions between the experiential and propositional aspects of knowledge. Thus, their empirical data entailed video recordings (living pictures), concrete materials, photos, written notes etc. This leads us to the next layer in the model: the methods.

\section{Methods - Creativity and systemacy in self-study}

When it comes to methods for studying own craft practice, two important questions surface: How can we gather relevant empirical data (methods) and how can we generate knowledge from this data (analysis)? (Figure 9). 


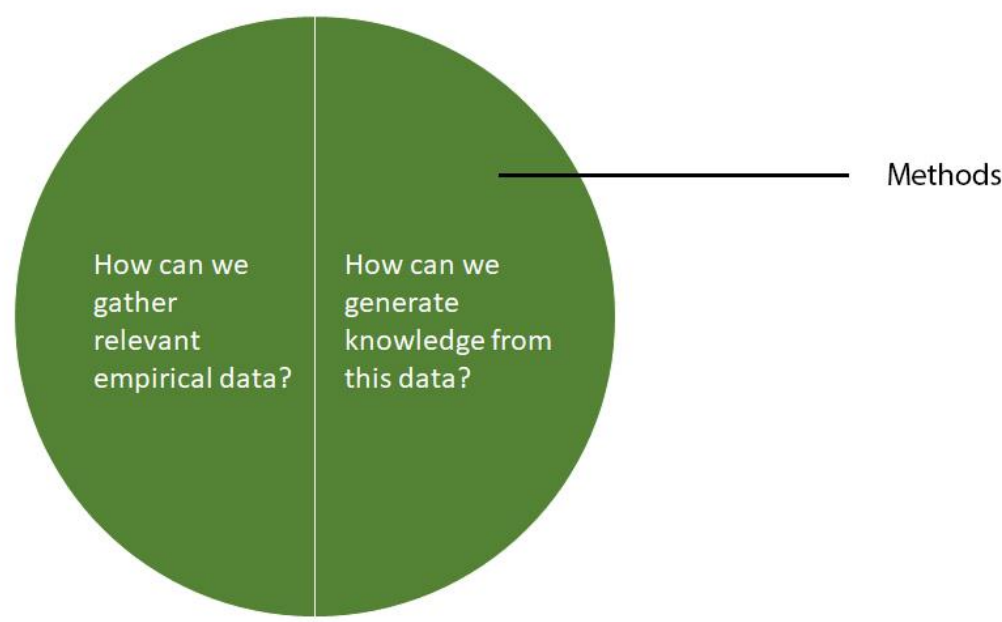

FIGURE 9. Model illustrating two aspects of methods.

Both Groth and Riis intended to investigate, analyse and communicate knowledge about craft practice through multiple methods of data collection and various ways of analysing the data in order to be able to capture different aspects of the practice. Both Groth and Riis had methodological references to autoethnography (Ellis \& Bochner, 2000). 'Auto' means 'self' as the researcher herself is object of observation, reflection and investigation. According to Baarts (2010); 'Ethno' means 'culture' and refers to the context of the experiences investigated, and 'graphy' refers to qualitative method where personal experiences and observations becomes research (p. 155).

In Groth's study and case 1, the main task of the study was to map out unique processes related to creative working in a setting where the touch sense is enhanced using methods such as participant observation, co-creation in workshops, semi-structured interviews, video documentation and field notes. In case 2, Groth used a practice-led autoethnographic research setting in which she documented her own practice through three methods. Firstly, she used a diary method (Bolger et al., 2003), where she wrote a diary answering specific questions and prompts just before starting the throwing session and also just after finishing. Secondly, she used an event sampling method, the contextual activity sampling system (CASS) (Muukkonen et al., 2008). CASS is a research instrument that uses mobile phones for sampling various aspects of learning, designing or making in their actual context of occurence. Thirdly, she used to think aloud accounts combined with video recordings (Ericsson \& Simon, 1993) which means that she collected all her spoken thoughts about the process of making while talking to the camera during her practice on the potter's wheel.

In the analysis of these data, Groth also made use of several methods, such as using a special video analysis tool and creating a protocol analysis of the actions and verbal accounts as well as paying special attention to the critical incidents (Flanagan, 1954) in the process. In the third case, Groth investigated the students' diary notes, weekly reflections and final project reports as well as conducting interviews. She first macro-analysed all data gathered during two years involving 19 students in total. The data sources chosen for the deeper analysis consisted of two students and their own diary notes, drawings, photographs, weekly reflections and final reflections produced during the courses. Groth conducted content analysis, based on the theoretical framing through colour coding (Fereday \& MuirCochrane, 2006).

Empirical data in Riis's study was documentation from the design process, including sewing and knitting trials, sketches, photos, notes etc., and video recordings from the workshop. The empirical data were transcribed and analysed in the research software Nvivo. Riis created an interplay between analysis in Nvivo and her work with structuring and analysing the data in multimodal schemes. Her work 
with the multimodal analysis schemes was influenced by content analysis (Krippendorf, 2019) and multimodal analysis (Jewitt, 2011), and this provided an overview of the huge amount of data, noted the methodological reflections, and established the initial analytical focus points.

Some focus points were chosen to be elaborated through thick descriptions and structured to depict examples on learning. Based on the principle of relative autonomy of examples (Molander, 2015, p. 229), the intention for Riis was to generate knowledge about design knowledge through detailed examples and descriptions of experiences and actions. Different examples from the design process were described in detail and structured in meaningful relationships as verbal and multimodal text, illustrations and concrete forms.

The structured data collection methods, i.e. CASS in Groth's case, freed up mental space to concentrate on the practice. Riis tried out both structured and unstructured video documentation and experienced a stronger awareness in the design process working with structured recordings, file management, and overview documentation. Thus, rigor and structure did not challenge creativity, rather the opposite. Analysing video from the making processes facilitated the dynamics between embodied experiences and conceptual understanding of these. Leaning only on memory in research can be both risky and unhelpful (Mäkelä \& Nimkulrat, 2018; Robinson \& Clore, 2002). Documentation helps with this task, and sometimes it might also show another reality than what is remembered. As such, video, on the one hand, helps distancing oneself from the making and to be analytical and reflective. On the other hand, it helps to keep in contact with the experiences during the making process as well as afterwards.

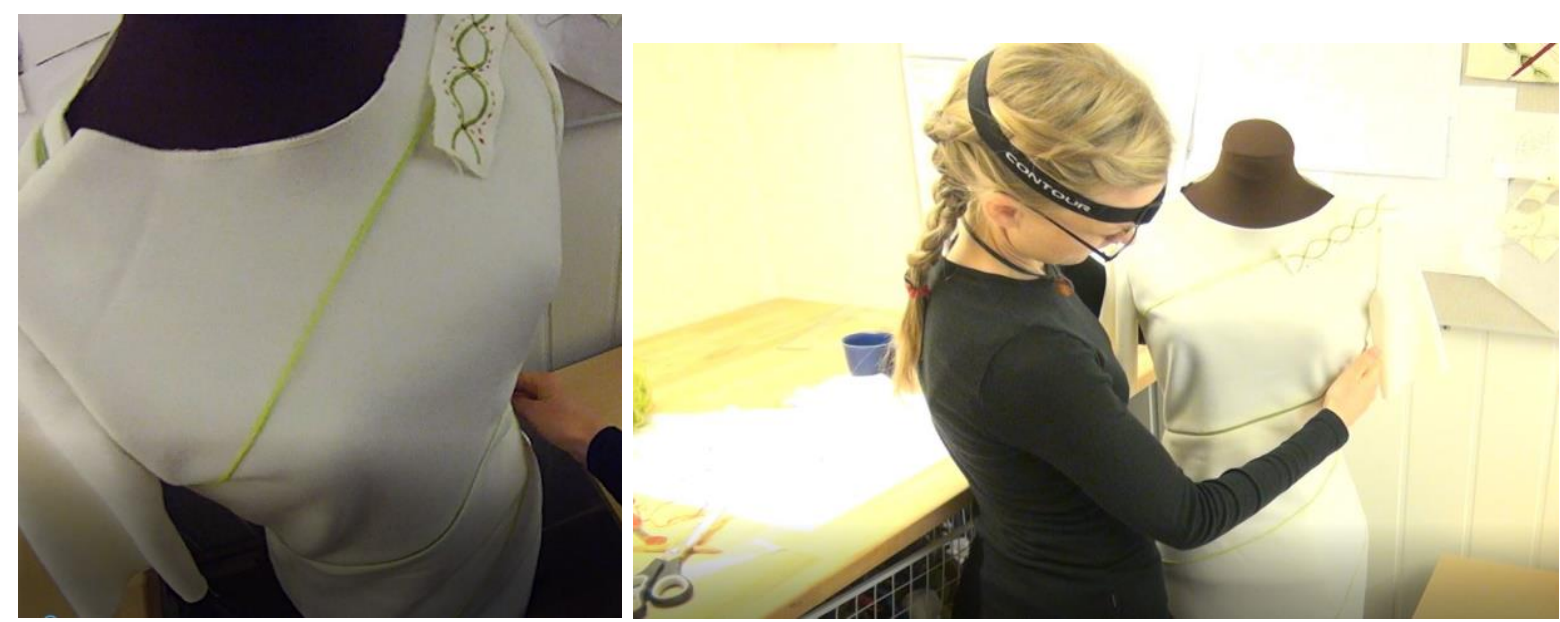

FIGURE 10 and 11. Screenshot image from the side camera video (figure 10). Screenshot image from the head camera video (figure 11).

A video shot by a head camera (figure 10 and 13) enables close proximity to the actual actions. The perspective from a camera placed on the side (figure 11 and 12) gives a distanced perspective, which stimulates analytical distance. It also makes it easier to see - and remember - gestures and how one acts and moves from a distance. 


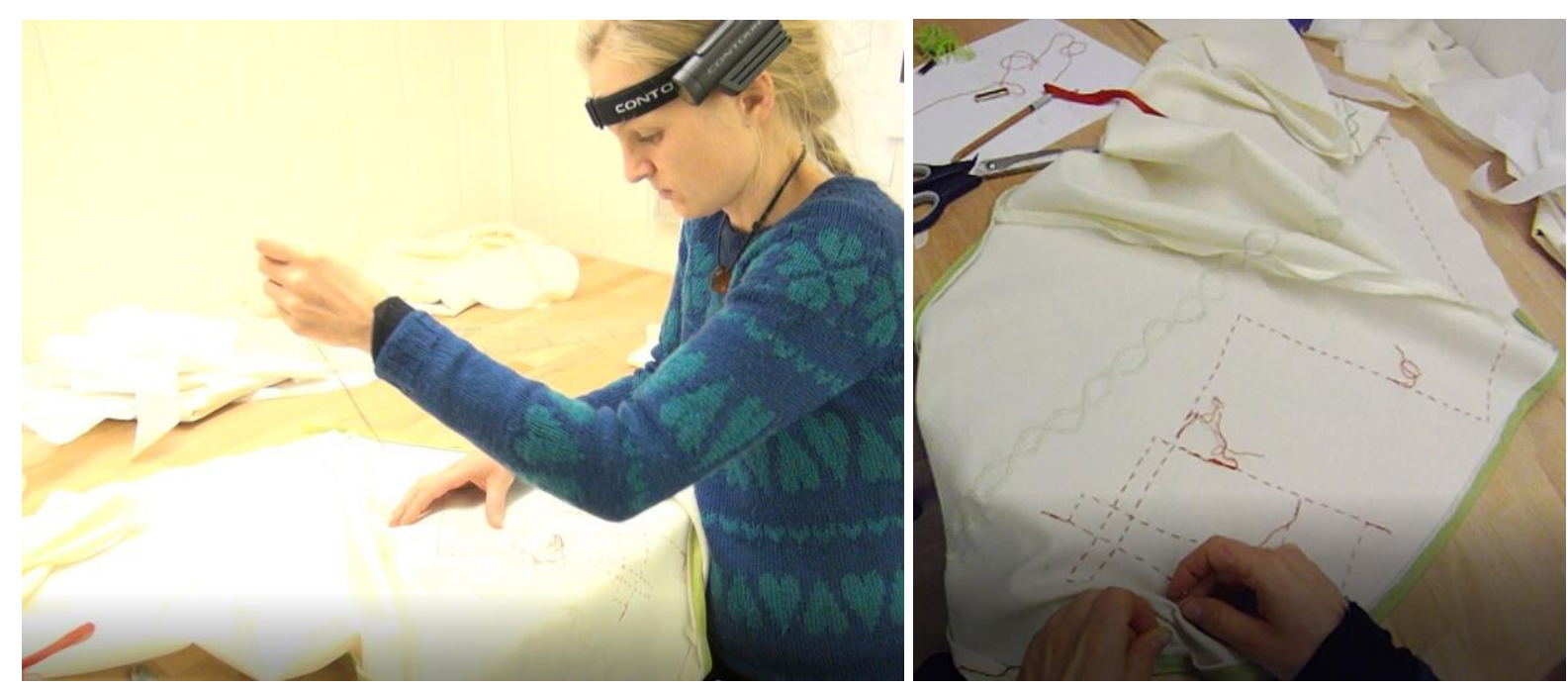

FIGURE 12 and 13. Screenshot image from the side camera (figure 12). Screenshot image from a head camera. Screenshot image from the side camera video (figure 13).

In Groth's research, the video was shot at a distance, from the front (Figure 14). In her case, the documentation allowed her to revisit the situation of working, that was conducted blindfolded but now visually presented in the video, through analysing the video in slow motion. She also collected think aloud accounts during the clay throwing process, which not only kept track of what the situation was about but also conveyed the different problems encountered and the way these were solved or the emotions linked to these situations - they became thick descriptions of the situations.

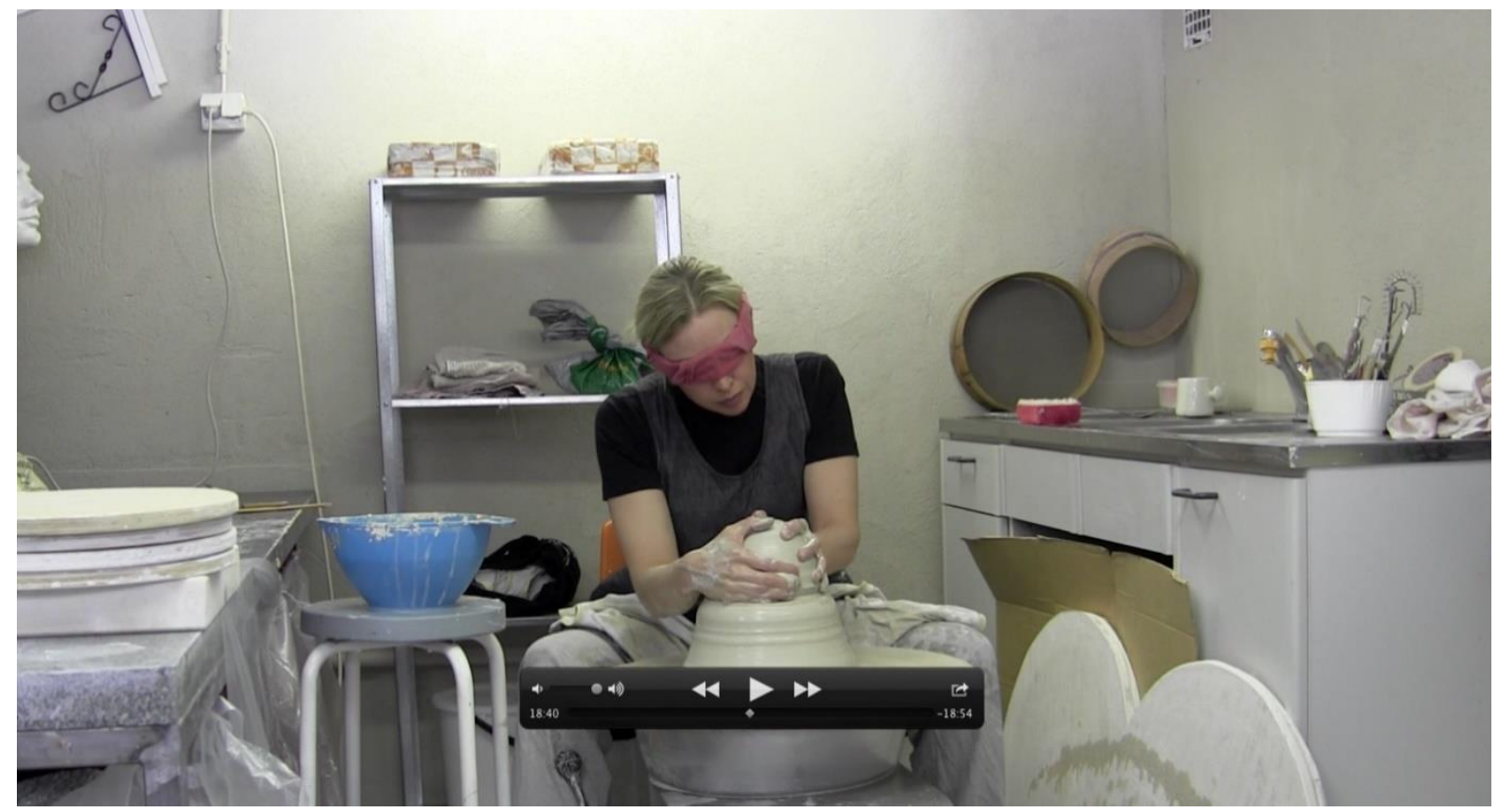

FIGURE 14. Audio visual documentation of Groth's blindfolded throwing process. Videoclip from the event.

When an action is documented audio visually, it is possible to look at it in slow motion; thus, this format allowed us see more than we would see only with our eyes. Distanced analysis of video documentation caused stimulated recalls of experiences, and both researchers maintained that an outsider researcher who had not participated in the actions themselves could not have made the analysis. Thus, both researchers claim that the subjective analysis was necessary for the information to be extracted. 
Through navigating the theoretical, epistemological and methodological aspects in these two examples, we found some general issues related to challenges and opportunities that we believe are encountered by many novice researchers in the creative practices. These will be discussed in the following section.

\section{CHALLENGES AND OPPORTUNITIES}

We have in the introduction looked into what research may entail in the field of creative practice and in craft in particular. Through the presented cases, we have given two examples of studies of craft practice, conducted from an insider perspective while aiming to keep a general relevance. We have discussed some theories that could be relevant in explorations of experiential knowledge and looked into aspects of handling the relationship between practice and research. In the following concluding section, we will describe the general challenges and opportunities encountered and elaborate on the following issues that emerged in the processes described above: how different research environments affect the choice of methodology, how personal knowledge can be handled and conveyed in a way that becomes relevant for others and how to balance different roles during the research - being both the practitioner and the researcher (and teacher).

In the concluding section, we will also discuss what relevance craft research potentially has for the practice field and related education and research.

\section{How different research environments affect the choice of methodology}

The different institutions and existing research traditions might affect the choices and direction of the novice researchers' approach. Traditions and 'unspoken truths' often affect research groups, networks, programs, universities etc. either explicitly or implicitly, intentionally or unintentionally. If the research topic is well covered by the institution, colleagues and supervisors, this will aid in finding references and provide ready-made methodologies. But the handed down methodology may not actually address all research questions. Sometimes, it can be a good idea to look further than the home institution for influences.

To critically reflect on these issues is challenging, especially when navigating the field for the first time, but will strengthen the novice researcher's independency and capability to develop their researcher identity at an earlier stage. Over time, the doctoral candidate grows out of the research environment, specific contexts and the 'research heroes' and struggles to become independent during this process: this is how they to grow into doctorateness (Nilsson \& Dunin-Woyseth, 2012). The research environment might provide both a comfortable and safe backdrop but revolting against this and finding new vistas might create breaking points that also open doors for researchers to come.

Any chosen research approach might both facilitate and hinder the progress of the research if it has been outlined too strictly before the start of the project. The very point of practice-led research is that the practice leads to both the progression of the research and the emergence of the most relevant research questions; thus, the methods that are most convenient for those research questions need to be in line with the demands posed by the situation and what the practice affords.

The research tradition in the field has not developed many 'on the shelf' methods that would be easily available regardless of context. Therefore, researchers often need to find their own methods through exploration, and this takes both time and effort, and may also lead to confusion and despair in the beginning of the process. However, based on our experience, we believe that in the realm of the arts, creative practitioners have special qualifications to handle this type of explorative process based on experiences from their practice field, since similar open-ended processes, material resistances and the handling of continuous risk are also faced in creative practice. It therefore seems important to keep the tension between systematic documentation and creative exploration along the research process.

\section{How personal knowledge can be handled and conveyed in a way that becomes relevant for others}

A challenge in an autoethnographic setting is how to handle subjective understandings and reflections so that they contribute to generalisable knowledge for others, both in the context of the research and in the professional practice field. A reflection on practice through a theoretical lens that works on a 
more general level helps find intersubjective aspects of the research. Intersubjectivity is, for this kind of research, about being transparent and exposing one's reflections of methodological and theoretical assumptions that underlie the current exploration.

Here, the challenge turns into an opportunity to utilise experienced craft practitioners' embodied knowing in the process of theorising practice. This is important, for example, in developing research-based pedagogy in the field of crafts, not only in the teacher education or arts and crafts context but also in the field of vocational craft education. Generating theory on practice might be considered more generalisable by the fact that many practice fields share similar general features, such as the embodiment of processes and experiential knowledge of materials, event-contingent progressions and the managing of creative open-ended processes.

The courage to defend subjective sense-making and its relevance in the research arena takes time to build up. Different ways of arguing for its importance in relation to the objective view gains more weight and substance as the practice-led research contributions keep developing and maturing. Each research project adds to the available repertoire of research methods, which not only inspires other researchers but also builds and develops the methodological and epistemological context of craft research in a constructive manner. As craft practice is based on personal knowledge about handling materials and event-contingent actions, it is also important to keep the research close to these events - and to analyse the events from an insiders' perspective.

\section{How to balance different roles during the research - being both the practitioner and the researcher (and teacher)}

When the researcher is both the participant and the researcher, there is a notion of a dual perception of the processes. This notion has been described as wearing 'two hats' (Biggs \& Büchler, 2011, pp. 7273; Borgdorff, 2006; Elo, 2009). Both researchers in this article's examples were wearing two or three hats at the same time, being both craftspersons and researchers, and Riis also having the perspective of being a teacher.

In their article, 'Design Education, Practice, and Research: On Building a Field of Inquiry', Nilsson and Dunin-Woyseth (2014) emphasized the synergy amongst the three roles as practitioner, teacher and researcher and claimed that teaching is an essential and mediating component. They wrote: 'We found that their extended profile from the dyadic (professional and teaching) practice has expanded to become a triadic one (professional, teaching, and research) and that each role has enriched the others' (pp. 12-13).

Groth and Riis expressed different views on this matter. In Groth's case, she did not feel that she was wearing the two hats at the same time but changed between these roles to be able to reflect on her practice in action and later on action, respectively. In Riis's case, she felt that she was wearing all three hats at the same time. Both researchers agreed that video documentation was useful to facilitate both the creative process and the documentation and reflection on the practice. Awareness of this situation before adopting an autoethnographic stance might help in developing one's own strategies for dealing with this issue, and to develop suitable methods for facilitating an organised and purposeful documentation and analysis of the data.

\section{CONCLUDING REMARKS}

One last question to answer is this: What relevance does craft research potentially have for the practice field and related education and research? Both researchers have been asked questions such as: Did your research change you as a practitioner? There seems to be a concern that the research of the practice would harm the practice and uncover its magic or the ability for intuitive making processes. Both researchers found that the opposite was true. The elevated understanding of the processes provided an opportunity to see the practice more clearly and to allow for more resources and attentiveness to be applied to the actions.

Both researchers now feel better equipped to see patterns and knowledge formations in their practice. Compared with a practitioner in the field who is interested in new knowledge for advancing 
the activity in the individual studio, the added research training gives the practitioner-researcher skills and intrinsic motivations to analyse the activity for a more general benefit and theory building. This added motivation for researching not only for personal benefit but for the sake of the betterment of the general practice field also adds to the persistence in articulating the practice from within.

Instead of questioning the relations between practice and research, we prefer to consider it a knowledge generating premise and potential. We consider practice-led research useful in practicecontexts as this gives the practitioner a voice that encourages the practice fields to engage in theories of practice on a general level and practitioners and novice researchers to think of their practice as meaningful on multiple levels. Thus, the making practice does not only facilitate research, but research practices also facilitate making practices.

\section{ACKNOWLEDGEMENTS}

This article was written as a joint endeavour between the two authors. We are much obliged to the two peer reviewers who gave constructive advice and encouragement and to our colleagues at the USN who offered peer reading and comments during the process of writing this contribution. 


\section{REFERENCES}

Aktaş, B. M., \& Mäkelä, M. (2019). Negotiation between the maker and material: Observations on material interactions in felting studio. International Journal of Design, 13(2), 55-67. http://www.ijdesign.org/index.php/IJDesign/article/view/3267/857

Almevik, G. (2019). Hantverksvetenskap och vetenskapligt hantverk. Om utvärdering av lärandemål i hantverksinriktad högskoleutbildning [Science in crafts and the craft of science: Craft-oriented programs in Swedish national higher education assessments]. FormAkademisk, 12(1), 1-14. https://doi.org/10.7577/formakademisk.2310

Baarts, C. (2010). Autoetnografi. [Autoethnography.] In S. Brinkmann \& L. Tangaard (Eds.), Kvalitative metoder . [Qualitative methods.] (pp. 153-164). Hans Reizels Forlag.

Biggs, M., \& Büchler, D. (2011). Transdisciplinarity and new paradigm research. In I. Doucet \& N. Janssens (Eds.), Transdisciplinary knowledge production in architecture and urbanism (pp. 63-68). Springer.

Biggs, M., \& Karlsson, H. (2011). Evaluating quality in artistic research. In M. Biggs \& H. Karlsson (Eds.), The Routledge companion to research in the arts (pp. 405-425). Routledge.

Bolger, N., Davis, A., \& Rafaeli, E. (2003). Diary methods: Capturing life as lived. Annual Review of Psychology, 54(1), 579-616. https://doi.org/10.1146/annurev.psych.54.101601.145030

Bologna Working Group on Qualifications Frameworks (2005). A framework for qualifications of the European higher education Area. Copenhagen, Ministry of Science, Technology and Innovation.

http://ecahe.eu/w/images/7/76/A_Framework_for_Qualifications_for_the_European_Higher_Educatio n_Area.pdf

Borgdorff, H. (2006). The debate on research in the arts. Sensuous Knowledge, 2, 7-21.

Borgdorff, H. 2012. The conflict of the faculties: Perspectives on artistic research and academia. Leiden University Press.

Campbell, K. H. (2013). A call to action: Why we need more practitioner research. Democracy \& Education, 21(2), 7. https://democracyeducationjournal.org/cgi/viewcontent.cgi?article=1133\&context=home

Candy, L., \& Edmonds, E. (2018). Practice-based research in the creative arts, foundations and futures from the frontline. Leonardo, 51(1), 63-69. https://doi.org/10.1162/LEON_a_01471

Capjon, J. (2004). Trial-and-Error-based Innovation: Catalysing Shared Engagement in Design Conceptualisation. [Doctoral dissertation]. The Oslo School of Architecture and design.

Charmaz, K. (2014). Constructing grounded theory (2nd ed.). Sage Publications.

Cross, N. (2001). Design cognition: Results from protocol and other empirical studies of design activity. In Eastman, C. M. McCracken, W. M., \& W. C. Newstetter (Eds.), Design knowing and learning: Cognition in design education (pp. 79-103). Elsevier.

Denzin, N. K., \& Lincoln, Y. S. (2011). Introduction: The discipline and practice of qualitative research. In N.K. Denzin \& Y. S. Lincoln (Eds.), Handbook of qualitative research (4th ed., pp. 1-10). SAGE Publications.

Dewey, J. (1934/2005). Art as experience. Berkley Publishing Group.

Dunin-Woyseth, H., \& Nilsson, F. (2012). Doctorateness in design disciplines. FORMAkademisk, 5(2), 1-11. https://doi.org/10.7577/formakademisk.499

Dunin-Woyseth, H, \& Michl, J. (2001). Towards a disciplinary identity of the making professions: An introduction. In H. Dunin-Woyseth \& J. Michl (Eds.), Towards a disciplinary identity of the making professions. (Vol. 4, pp. 1-20). Oslo School of Architecture..

Ellis, C., \& Bochner, A. P. (2000). Autoethnography, personal narrative, reflexivity: Researcher as subject. In N. K. Denzin \& Y. S. Lincoln (Eds.), Handbook of qualitative research (2nd ed., pp. 733-768). SAGE Publications. 
Elo, M. (2009). Passages of articulation: Art and research touching. In N. Nimkulrat \& T. O’Riley (Eds.), Reflections and connections: On the relationship between production and academic research (pp. 19-26). University of Art and Design Helsinki, Finland.

Eriksson, J. (2019). Kalkbruk - krympsprickor och historisk utveckling av material, metoder och förhållningssätt. [Lime mortar - shrinkage cracks and historical development of materials, methods and approaches]. Doctoral dissertation, University of Gothenburg: Studies in Conservation, Acta Universitatis Gothoburgensis.

Eriksson, L., Seiler, J., Jarefjäll, P., \& Almevik, G. (2019). The time-space of craftsmanship. Craft Research Journal, 10(1), 17-39. https://doi.org/10.1386/crre.10.1.17_1

Ericsson, K. A., \& Simon, H. A. (1993). Protocol analysis: Verbal reports as data. The MIT Press (Original work published 1984)

Eskola, T. (1997). Water lilies and wings of steel: Interpreting change in the photographic imaging of Aulanko park [Doctoral dissertation], University of Art and Design, Helsinki.

Fauske. L. B. (2014). Å etablere et akademisk formingsfaglig miljø. Tilbakeblikk på den tidlige fasen for hovedfag i forming [Developing a research community of art and design education. Looking back at the early phase of the master's programme in art and design education]. FORMakademisk, 7(5), 1-16. https://doi.org/10.7577/formakademisk.930

Fauske, L. B. (2016). Reforhandling av kunnskapsgrunnlag. Forskning og fagutvikling med utspring i designdidaktikk. [Renegotiation of knowledge base. Research and professional development originating in design didactics.]. Techne Series A, 23(2), 50-68. https://journals.hioa.no/index.php/techneA/article/view/1560

Fereday, J., \& Muir-Cochrane, E. (2006). Demonstrating rigor using thematic analysis: A hybrid approach of inductive and deductive coding and theme development. International Journal of Qualitative Methods, 5(1), 80-92. https://doi.org/10.1177/160940690600500107

Flanagan, J. C. (1954). The critical incident technique. Psychological Bulletin, 51(4), 327. https://doi.org/10.1037/h0061470

Frayling, C. (1994). Research in art and design. Royal College of Art Research Paper, 1(1), 1-9. https://researchonline.rca.ac.uk/384/3/frayling_research_in_art_and_design_1993.pdf

Fredriksen, C. B. (2011). When past and new experiences meet. FORMakademisk, 4(1), 65-80. https://doi.org/10.7577/formakademisk.128

Glitsch, V. S. (2020). Fit step in ready-to-wear clothing. Towards a reduction of garment disposal in view of sustainability. [Doctoral thesis University of South-Eastern Norway, Norway]. http://hdl.handle.net/11250/2635801

Groth, C. (2017). Making sense through Hands: Design and craft practice analyzed as embodied cognition [Doctoral dissertation, Aalto Arts Books]. https://aaltodoc.aalto.fi/bitstream/handle/123456789/24839/isbn9789526071305.pdf?sequence=1\&is Allowed=y

Gherardi, S. (2000). Practice-based theorizing on learning and knowing in organizations. Introduction to the special issue on knowing in practice. Organization 7(2), 211-223. https://doi.org/10.1177/135050840072001

Handling Mind. (n.d.) https://blogs.helsinki.fi/handling-mind/

Hartvik, J. (2014). Det planlagda och det som visar sig: Klasslärarstuderandes syn på undervisning i teknisk slöjd. [The planned and what turns out: The class teacher student's view of teaching technical handicraft.] [Doctoral dissertation, Åbo Akademi University Press]. http://urn.fi/URN:ISBN:978-951-765-717-4

Hasling, K. M. (2015, Oct 23). Learning through materials: Developing materials teaching in design education. [Doctoral thesis], Design School Kolding.

Hasselskog, P. (2010). Slöjdlärares förhållningssätt i undervisningen. [Handicraft teacher's approach in teaching [Doctoral dissertation, Göteborgs universitet, Fakulteten för Utbildningsvetenskap. University of 
Gothenburg, Studies in Educational Science, 289]. Göteborg: Acta Universitatis Gothoburgensis, http://hdl.handle.net/2077/21997

Høgseth H. B. (2007). Håndverkets redskapskasse: En undersøkelse av kunnskapsutøvelse i lys av arkeologisk bygningstømmer fra 1000-tallet e. Kr. [The craft toolbox: A study of the exercise of knowledge in the light of archaeological timber building from the 1000s AD.] [Doctoral dissertation, The Norwegian University of Science and Technology NTNU]. http://hdl.handle.net/11250/242854

Ingold, T. (2011). Being alive: Essays on movement, knowledge and description. Routledge.

Jarefjäll, P. (2016). Navarsmide: en metodstudie ur ett hantverksperspektiv. [Navarsmide: a method study from a craft perspective.] [Licensiate thesis: University of Gothenburg, Department of conservation]. http://hdl.handle.net/2077/45888

Jewitt, C. (2011). The Routledge handbook of multimodal analysis. Routledge.

Johansson, M. (2002). Slöjdpraktik i skolan - hand, tanke, kommunikation och andra medierande redskap. [Handicraft practice in school- hand, thought, communication and other mediating tools.] [Doctoral dissertation. Göteborgs universitet, Fakulteten för Utbildningsvetenskap. University of Gothenburg, Studies in Educational Science, 183]. Göteborg: Acta Universitatis Gothoburgensis. http://hdl.handle.net/2077/15749

Johansson, M. (2018). Doktorsavhandlingar inom det nordiska slöjdfältet. [Doctoral dissertations in the Nordic handicraft field.] Techne Serien A: 25(3), 109-123. https://journals.hioa.no/index.php/techneA/article/view/3031

Johnson, M. (2007). The meaning of the body. Chicago University Press.

Krippendorff, K. (2019). Content analysis: An introduction to its methodology (4th ed.). SAGE Publications.

Kokko, S. (2018). The role of higher education in sustaining culturally significant crafts in Estonia. In S. Walker, M. Evans, M., T. Cassidy, A. T. Holroyd, \& J. Jung (Eds.), Design roots. Culturally significant designs, products and practices (pp. 231-242). Bloomsbury Academic.

Kokko, S., Almevik, G., Høgseth, H. \& Seitamaa-Hakkarainen, P. (in press). Mapping the methodologies of the craft sciences in Finland, Sweden and Norway. Craft Research, 11(2).

Källbom, A., Nilsen, A., \& Öström, Å. (2019). Olfactory description for refined linseed oils for paints: Characterization for reconstructing material and craft knowledge in paintmaking. Journal of Sensory Studies 34(2), 1-10. https://doi.org/10.1111/joss.12485

Lakoff, G., \& Johnson, M. (1980). Metaphors we live by. University of Chicago Press.

Lakoff, G., \& Johnson, M. (1999). Philosophy in the flesh: The embodied mind and its challenge to Western thought. Basic Books.

Lave, J., \& Wenger, E. (1991). Situated learning. Legitimate peripheral participation. Cambridge University Press.

Lindfors, E. (2002). Tekstiilituotteen teknologiset ominaisuudet. Tekstiilituotteen käyttö ja hoito ominaisuuksien tarkastelu kuluttajan näkökulmasta. [Technological characteristics of the textile product. Examination of the use and care properties of a textile product from the consumer's point of view]. Publications in Education, 77. University of Joensuu

Livholts, M. (2015a). Untimely academic novella writing. In Livholts, M. \& Tamboukou, M. (Eds.), Discourse and narrative methods: Theoretical departures, analytical strategies and situated writing (pp. 177-171). SAGE Publications

Luhmann. N. (2007). Indføring i systemteorien. (Edt: Madsen , C.) København; Unge pædagoger.

McGuirk, J., \& Methi, J. (2015). Praktisk kunnskap som profesjonsforskning : Antologi over yrkeserfaringen som utgangspunkt for forståelse av kunnskapsutvikling i praksis. [Practical knowledge as professional research: Anthology of professional experience as a starting point for understanding knowledge development in practice. ] Fagbokforlaget.

Medbo, M. (2016). Lerbaserad erfarenhet och språklighet [Clay based experience and languageness] [Doctoral thesis, Faculty of Fine, Applied and Performing Arts, University of Gothenburg]. ArtMonitor. 
Molander, B. (2015). The practice of knowing and knowing in practices. Peter Lang.

Muukkonen, H., Hakkarainen, K., Inkinen, M., Lonka, K., \& Salmela-Aro, K. (2008, June, 23-28). CASS-methods and tools for investigating higher education knowledge practices. In G. Kanselaar, V. Jonker, P. Kirschner, \& F. Prins (Eds.), International perspectives in the learning sciences: Cresing a learning world, 2, 107-114. Proceedings of the eight international conference for the learning sciences (ICLS 2008), Utrecht, The Netherlands.

Mäkelä, M. (2007). Knowing through making: The role of the artefact in practice-led research. Knowledge, Technology \& Policy, 20(3), 157-163. https://doi.org/10.1007/s12130-007-9028-2

Mäkelä, M., \& Nimkulrat, N., (2018). Documentation as a practice-led research tool for reflection on experiential knowledge. FORMAkademisk, 11(2), 1-16. https://doi.org/10.7577/formakademisk.1818

Mäkelä, M. (2016). Personal exploration: Serendipity and intentionality as altering positions in a creative process. FORMakademisk, 9(1), 1-12. https://doi.org/10.7577/formakademisk.1461

Mäkelä, M, Nimkulrat, N., Dash, D. P., \& Nsenga, F.-X. (2011) On reflecting and making in artistic research, Journal of Research Practice, 7(1), Article E1. http://jrp.icaap.org/index.php/jrp/article/view/280/241

Mäkelä, M., \& Nimkulrat, N. (2011, May 29-31). Reflection and documentation in practice-led design research. In I. Koskinen, T. Härkäsalmi, R. Mazé, Matthews, B. \& Lee, J. J. (Eds.), Making design matter. Proceedings of the 4th Nordic Design Research Conference NORDES, Helsinki, Finland, pp. 120-128.

Mäkelä, M. \& Nimkulrat, N. (2018). Documentation as a practice-led research tool for reflection on experiential knowledge. FORMAkademisk, 11(2), 1-16. https://doi.org/10.7577/formakademisk.1818

Nicolini, D. (2009). Zooming in and out: Studying practices by switching theoretical lenses and trailing connections. Organization Studies 30(12), 1391-1418. https://doi.org/10.1177/0170840609349875

Niedderer, K. (2013). Explorative materiality and knowledge: The role of creative exploration and artefacts in design research. FORMAkademisk, 6(2), 1-20. https://doi.org/10.7577/formakademisk.651

Nielsen, L. M. (2018). Building making scholarship. FORMakademisk, 11(1). https://doi.org/10.7577/formakademisk.3099

Nimkulrat, N. (2012). Hands-on intellect: Integrating craft practice into design research. International Journal of Design, 6(3), 1-14. http://www.ijdesign.org/index.php/IJDesign/article/view/1228

Noë, A. (2004). Action in perception. The MIT press.

Noë, A. (2009). Out of our heads. Hill and Wang.

Nyström, I. (2020). Konstteknologisk källforskning med ett hantverks- och konserveringsvetenskapligt perspektiv. [Art technology source research with a craft and conservation science perspective]. In Eds. Nyström, Knutsson \& Palmsköld 2020, Hälsinglands inredningskultur. Mackadam. https://doi.org/10.22188/kriterium.23

Pinnegar, S., \& Hamilton, M. L. (2009). Self-study of practice as a genre of qualitative research: Theory, methodology, and practice. Springer.

Polanyi, M. (1966). The tacit dimension. Doubleday.

Pöllänen, S. (2015). Elements of craft that enhance well-being. Textile craft makers' descriptions of their leisure activity. Journal of Leisure Research, 47(1), 58-78. https://doi.org/10.1080/00222216.2015.11950351

Refsum, G. (2000). Genuine Christian Modern Art : Present Roman Catholic Directives on Visual Art Seen from an Artist's Perspective. [Doctoral dissertation, The Oslo School of Architecture and design]. http://hdl.handle.net/11250/2601253

Robinson, M. D., \& Clore, G. L. (2002). Episodic and semantic knowledge in emotional self-report: Evidence for two judgment processes. Journal of Personality and Social Psychology, 83(1), 198-215. https://doi.org/10.1037/0022-3514.83.1.198 
Riis, K. (2016). Designkundskabens DNA: Udforskning af designkunskab gennem designprocessen Mit DNA. [The DNA of design knowledge: Exploration of design knowledge through the design process My DNA.] [Doctoral dissertation. The Norwegian University of Science and Technology NTNU]. https://ntnuopen.ntnu.no/ntnu-xmlui/handle/11250/2393093

Rust, C. Mottram, J., \& Till, J. (2007). Review of practice-led research in art, design \& architecture. Arts and Humanities Research Council, Bristol, UK. http://shura.shu.ac.uk/7596/1/Pactice-ledReviewNov07.pdf

Sawyer, R. (2006). The Cambridge handbook of the learning sciences. Cambridge University Press.

Schön, D. (1983). The reflective practitioner: How professionals think in action. Basic Books.

Seiler, J. (2020). Management Regimes for lawns and hedges in historic gardens [Doctoral dissertation, University of Gothenburg, Department of Conservation]. http://hdl.handle.net/2077/62813

Seitamaa-Hakkarainen, P., \& Hakkarainen, K. (2001). Composition and construction in experts' and novices' weaving design. Design Studies, 22(1), 44-66. https://doi.org/10.1016/S0142-694X(99)00038-1

Sennett, R. (2009). The craftsman. Penguin Books.

Stenslie, S. 2010 Virtual touch: a study of the use and experience of touch in artistic, multimodal and computerbased environments. [Doctoral dissertation, The Oslo School of Architecture and design]. http://hdl.handle.net/11250/93049

Solberg, A. (2017). Developing doctorateness in art, design and architecture [Doctoral dissertation no. 15, Faculty of Humanities, Sports and Educational Sciences, University College of Southeast Norway]. http://hdl.handle.net/11250/2442970

Westerlund, T., Groth, C., \& Almevik, G. (in press). Craft sciences. Göteborg: Acta Universitatis Gothoburgensis, Studies in Conservation.

Yin, R. K. (2003). Case study research: Design and methods. SAGE Publications. 